\title{
Isomers in the Chemistry of Germanium Heterometallic Clusters
}

\author{
Milan Melník* and Jan Garaj
} Department of Chemical Theory of Drugs, Faculty of Pharmacy, Comenius University, Odbojarov 2, 83232 Bratislava,
Slovak Republic

\begin{abstract}
Sixteen isomers of heterometallic germanium clusters have been analysed in this review. There are two types of isomerism, distortion (x 15) and cis - trans (x 1) and cis - isomer contains two crystallographically independent molecules. Distortion isomers, differing only by degree of distortion in $\mathrm{Ge}-\mathrm{L}, \mathrm{Ge}-\mathrm{M}(\mathrm{M}=$ metal) distances and $\mathrm{L}-\mathrm{Ge}-\mathrm{L}$ $(\mathrm{L}=$ ligand) angles. The data are discussed with these found in the isomerism of germanium coordination compounds as well as organogermanium derivatives. In the chemistry of germanium were found-seventy four derivatives as isomers. These are discussed and compared with those in tin (over two hundred and fifty examples) and lead (seventy examples) chemistry. This review and its precursors give the first overall survey of the structural data for the isomer complexes of the group IV metals.
\end{abstract}

Keywords: Germanium, heterometallic, clusters, isomers, crystal structures.

\section{INTRODUCTION}

The chemistry of germanium has been an active area of research in catalytic activity and reaction with organic species. Numerous structural studies have been carried out, including almost two hundred and fifty heterometallic germanium derivatives [1] with sixteen isomeric examples noted. In [2] we analysed and classified over twenty isomers in the chemistry of germanium coordination compounds. Another almost fifty isomeric examples in the chemistry of organogermanium compounds were also characterised and classified [3]. In this review we analyse and classify isomeric examples of germanium heterometallic derivatives to show a comprehensive view on the isomers in the chemistry of germanium.

\section{DISTORTION ISOMERISM}

The existence of two or more species differing by degree of distortion of $\mathrm{M}-\mathrm{L}$ bond distances and $\mathrm{L}-\mathrm{M}-\mathrm{L}$ bond angles is typical of the general class of distortion isomers [4]. There are fifteen such examples in the chemistry of germanium heterometallic derivatives and their crystallographic and structural data are summarised in Table 1.

Yellow $\mathrm{Cl}_{3} \mathrm{GeAu}\left(\mathrm{PPh}_{3}\right)_{3}$ [5] exists in two isomeric forms, both are monoclinic. In each of the derivative two non equivalent moieties, $\mathrm{Cl}_{3} \mathrm{Ge}$ and $\mathrm{Au}\left(\mathrm{PPh}_{3}\right)_{3}$ are held together by a direct $\mathrm{Ge}-\mathrm{Au}$ bond with the distances of 2.563(1) and 2.536(1) $\AA$, respectively. Each M atom is a tetrahedrally coordinated $\left(\mathrm{GeCl}_{3} \mathrm{Au}\right.$ and $\left.\mathrm{AuP}_{3} \mathrm{Ge}\right)$. The isomers differ from each other by degree of distortion and are examples of distortion isomerism. The mean $\mathrm{M}-\mathrm{L}$ bond distances of $\mathrm{Ge}-$ $\mathrm{Cl}=2.240(2)$ and $\mathrm{Au}-\mathrm{P}=2.425(1) \AA$ in isomer 1 and $2.233(2)$ and 2.457(1) $\mathrm{A}$ in isomer 2.

\footnotetext{
*Address correspondence to this author at the Department of Inorganic Chemistry, Slovak Technical University, Radlinskeho 9, 81237 Bratislava, Slovak Republic; Tel: +421 2 52495239; Fax: +421 2 52493198;
}

E-mail: milan.melnik@stuba.sk
In $\mathrm{GeCu}$ dimer [6], which contains two crystallographically independent dimers, two non equivalent units $\left(\mathrm{C}_{6} \mathrm{~F}_{5}\right)_{3} \mathrm{Ge}$ and $\mathrm{Cu}\left(\mathrm{PPh}_{3}\right)_{2}$ are also held together by a direct $\mathrm{Ge}-\mathrm{Cu}$ bond with the lengths of 2.370(2) and 2.382(3) $\AA$, respectively. While each $\mathrm{Ge}$ atom is tetrahedrally coordinated $\left(\mathrm{GeC}_{3} \mathrm{Cu}\right)$ the $\mathrm{Cu}$ atoms have a trigonal planar environment $\left(\mathrm{CuP}_{2} \mathrm{Ge}\right)$ the mean $\mathrm{Ge}-\mathrm{C}$ bond distances are 2.015 and $2.008 \AA$, respectively. Six tetrahedral angles $\mathrm{C}-\mathrm{Ge}$ $\mathrm{C}(\mathrm{Cu})$ range from 95.7 (3) to $121.6(2)$ and $95.1(3)$ to $122.8(3)^{\circ}$, respectively. This indicates that the former is somewhat less distorted than the latter. Noticeable, the $\mathrm{CuP}_{2} \mathrm{Ge}$ units follow the same trend (Table 1).

Another two dimers, GeMn [7] and GeSn [8] which also contain two crystallographically independent dimers, two non-equivalent units, $(\mathrm{Ph})_{3} \mathrm{Ge}$ and $\mathrm{Mn}(\mathrm{CO})_{5}[7]$ and $(\mathrm{Me})_{3} \mathrm{Ge}$ and $\mathrm{Sn}\left(\mathrm{Ph}_{3}\right)_{3}$ [8], are connected also by a direct $\mathrm{Ge}-\mathrm{M}$ bonds, 2.53(2) and 2.54(2) $\AA(\mathrm{M}=\mathrm{Mn})$ and 2.596(4) and 2.567(6) $\AA(\mathrm{M}=\mathrm{Sn})$. These are also classical examples of distortion isomerism (Table 1). Structure of orange $\mathrm{GeFe}$ dimer [9] is shown in Fig. (1). Two non-equivalent moieties $(\mathrm{Ph})_{3} \mathrm{Ge}$ and $\mathrm{Fe}(\mathrm{cp})$ are held together by the $\mathrm{C}_{5} \mathrm{H}_{4} \mathrm{CO}$ ligand via all six of the $\mathrm{C}$ atoms. It binds to $\mathrm{Fe}$ as $\eta^{5}-\mathrm{C}_{5} \mathrm{H}_{4}$, but as an acyl ligand to Ge, giving a sandwich complex geometry and a tetrahedral one, respectively. There are two crystallographically independent molecules. Unfortunately, the data are available only for one molecule (Table 1).

Structure of another orange GeFe dimer [10] is shown in Fig. (2). The $\mathrm{N}$ atom of the ferrocene amine base bonds to the capping $\mathrm{Ge}$ atom of the germanoborane. The Ge atom is unsymmetrical bonded to the atoms of the $\mathrm{C}_{2} \mathrm{~B}_{3}$ face, slipping towards the boron vide of the face to give distorted pentagonal-bipyramidal $\mathrm{GeC}_{2} \mathrm{~B}_{4}$ cage. The unit cell contains two crystallographically independent molecules differing in the relative orientation of the carborane and ferrocene amine ligands. In one, the $\mathrm{Ge}-\mathrm{N}$ bond (2.406(6) $\AA$ ) is slightly rotated out of this plane. 
Table 1. Crystallographic and Structural Data for Germanium Heterometallic Compounds - Distortion Isomers ${ }^{\mathrm{a}}$

\begin{tabular}{|c|c|c|c|c|c|c|c|c|}
\hline $\begin{array}{l}\text { Compound } \\
\text { (colour) }\end{array}$ & $\begin{array}{c}\text { Cryst.cl. } \\
\text { Space gr. } \\
\text { z }\end{array}$ & $\begin{array}{l}\text { a [Á́] } \\
\text { b [Á] } \\
\text { c [Ǻ] }\end{array}$ & $\begin{array}{l}\alpha\left[^{\circ}\right] \\
\beta\left[^{\circ}\right] \\
\gamma\left[^{\circ}\right]\end{array}$ & $\begin{array}{c}\text { Chromo- } \\
\text { phore }\end{array}$ & $\begin{array}{c}\mathbf{M}-\mathbf{L} \\
{[\mathbf{A ́}]}\end{array}$ & $\begin{array}{c}\mathbf{M}-\mathbf{M} \\
{\left[\begin{array}{c}\mathbf{A}] \\
\end{array}\right.}\end{array}$ & $\begin{array}{c}\mathbf{L}-\mathbf{M}-\mathbf{L} \\
{\left[^{\circ}\right]}\end{array}$ & Ref. \\
\hline $\begin{array}{l}\left(\mathrm{C}_{6} \mathrm{~F}_{5}\right)_{3} \mathrm{GeCu}\left(\mathrm{PPh}_{3}\right)_{3}(\text { not } \\
\text { given) }\end{array}$ & $\begin{array}{l}\operatorname{tr} \\
\mathrm{P}-1 \\
4\end{array}$ & $\begin{array}{l}13.339(7) \\
19.575(9) \\
19.829(12)\end{array}$ & $\begin{array}{l}98.2(4) \\
104.10(4) \\
94.62(4)\end{array}$ & $\begin{array}{l}\mathrm{GeC}_{3} \mathrm{Cu} \\
\mathrm{CuP}_{2} \mathrm{Ge} \\
\mathrm{GeC}_{3} \mathrm{Cu} \\
\mathrm{CuP}_{2} \mathrm{Ge}\end{array}$ & $\begin{array}{l}\text { C } 2.015(8,15) \\
\text { P } 2.263(3,7) \\
\text { C } 2.008(9,14) \\
\text { P } 2.273(3,1)\end{array}$ & $\mathrm{Cu} 2.370(2)$ & $\begin{aligned} \mathrm{C}, \mathrm{C} \mathrm{C}, \mathrm{Cu} 101.9(3,6.2) \\
109.8(2) \\
119.8(2,1.8) \\
\mathrm{P}, \mathrm{P} 123.1(1) \\
\mathrm{P}, \mathrm{Ge} 118.5(1,1.3) \\
\mathrm{C}, \mathrm{C} 105.2(4,3.2) \\
\mathrm{C}, \mathrm{Cu} 95.1(3) \\
121.7(3,1.1) \\
\mathrm{P}, \mathrm{P} 123.1(7) \\
\mathrm{P}, \mathrm{Ge} 118.4(1,3.3)\end{aligned}$ & [6] \\
\hline $\begin{array}{l}\left(\mathrm{PPh}_{3}\right) \mathrm{GeMn}(\mathrm{CO})_{5} \\
\text { (not given) }\end{array}$ & $\begin{array}{l}\operatorname{tr} \\
\mathrm{P}-1 \\
4\end{array}$ & $\begin{array}{l}11.38 \\
11.66 \\
17.17\end{array}$ & $\begin{array}{l}105.0 \\
97.8 \\
91.2\end{array}$ & $\begin{array}{l}\mathrm{GeP}_{3} \mathrm{Mn} \\
\mathrm{MnC}_{5} \mathrm{Ge} \\
\mathrm{GeP}_{3} \mathrm{Mn}\end{array}$ & $\begin{array}{l}\mathrm{Ph}_{3} \mathrm{P} \text { not given } \\
\mathrm{O}, \mathrm{C} \text { not given } \\
\mathrm{Ph}_{3} \mathrm{P} \text { not given }\end{array}$ & $\begin{array}{l}\text { Mn 2.53(2) } \\
\text { Mn 2.54(2) }\end{array}$ & $\begin{array}{l}\mathrm{P}, \mathrm{P} \text { not given } \\
\mathrm{P}, \mathrm{P} \text { not given }\end{array}$ & [7] \\
\hline $\begin{array}{l}(\mathrm{Me})_{3} \mathrm{GeSn}(\mathrm{PPh})_{3} \\
\text { (colourless) }\end{array}$ & $\begin{array}{l}\text { or } \\
\text { Pna2 } 2_{1} \\
4\end{array}$ & $\begin{array}{l}20.741(3) \\
12.393(2) \\
8.064(1)\end{array}$ & & $\begin{array}{l}\mathrm{GeC}_{3} \mathrm{Sn} \\
\mathrm{SnC}_{3} \mathrm{Ge} \\
\mathrm{GeC}_{3} \mathrm{Sn} \\
\mathrm{SnC}_{3} \mathrm{Ge}\end{array}$ & $\begin{array}{l}\text { MeC } 1.985(7,6) \\
\text { PhC } 2.095(7,4) \\
\text { MeC } 1.982(8,1) \\
\text { PhC } 2.091(7,0)\end{array}$ & $\begin{array}{l}\text { Sn 2.596(4) } \\
\text { Sn } 2.567(6)\end{array}$ & $\begin{array}{c}\text { C,C } 107.1(8,1.5) \\
\text { C,Sn } 111.8(7,2.2) \\
\text { C,C } 108.4(8,1.7) \\
\text { C,C } 111(2,2) \\
\text { C,Sn } 108.6(4,2.0) \\
\text { C,C } 106.8(2,4.5)\end{array}$ & [8] \\
\hline $\begin{array}{l}{\left[\left\{2,3-\left(\mathrm{Me}_{3} \mathrm{Si}\right)_{2}\right.\right.} \\
\left.\mathrm{C}_{2} \mathrm{~B}_{4} \mathrm{H}_{4}\right\} \mathrm{Ge} . \\
\left\{\mu-\mathrm{N}(\mathrm{Me})_{2} \mathrm{CH}_{2} \mathrm{C}_{5} \mathrm{H}_{4}\right\} \\
\left.\mathrm{Fe}\left(\eta^{5}-\mathrm{cp}\right)\right] \\
\text { (orange) }\end{array}$ & $\begin{array}{l}\operatorname{tr} \\
\mathrm{P}-1 \\
4\end{array}$ & $\begin{array}{l}12.633(3) \\
14.146(2) \\
17.407(4)\end{array}$ & $\begin{array}{l}102.65(2) \\
96.63(2) \\
110.65(2)\end{array}$ & $\begin{array}{l}\mathrm{GeB}_{2} \mathrm{C}_{2} \mathrm{~N} \\
\mathrm{FeC}_{10} \\
\mathrm{GeB}_{2} \mathrm{C}_{2} \mathrm{~N} \\
\mathrm{FeC}_{10}\end{array}$ & $\begin{aligned} \text { B } 2.238(9,60) \\
\text { C } 2.519(8,7) \\
\mu \mathrm{LN} 2.406(6) \\
\mathrm{cpC} \text { not given } \\
\text { B } 2.247(8,39) \\
\text { C } 2.448(6,5) \\
\mu \mathrm{LN} 2.496(6) \\
\mathrm{cpC} \text { not given }\end{aligned}$ & & not given & {$[10]$} \\
\hline $\begin{array}{l}\left(\mathrm{Ph}_{3} \mathrm{Ge}\right)_{2}(\mu-\mathrm{Hg}) \\
\text { (not given) }\end{array}$ & $\begin{array}{l}\operatorname{tr} \\
\mathrm{P}-1 \\
4\end{array}$ & $\begin{array}{l}7.660(2) \\
16.562(3) \\
19.220(4)\end{array}$ & $\begin{array}{l}79.04(1) \\
81.65(2) \\
81.68(2)\end{array}$ & $\begin{array}{l}\mathrm{GeC}_{3} \mathrm{Hg} \\
\mathrm{HgGe}_{2} \\
\mathrm{GeC}_{3} \mathrm{Hg} \\
\mathrm{HgGe}_{2}\end{array}$ & PhC 1.957(13,16) & $\begin{array}{l}\operatorname{Hg} 2.514(2,0) \\
\operatorname{Hg} 2.543(1,0)\end{array}$ & $\begin{array}{c}\text { C,C 108.1(5,1.5) } \\
\text { C,Hg } 110.2(4,2.1) \\
\text { Ge,Ge } 178.65(5) \\
\text { C,C } 106.9(5,1.6) \\
\text { C,Hg } 111.9(4,4.1) \\
\text { Ge,Ge } 180.0\end{array}$ & [11] \\
\hline
\end{tabular}


(Table 1). Contd......

\begin{tabular}{|c|c|c|c|c|c|c|c|c|}
\hline $\begin{array}{l}\left\{\mathrm{Me}_{3} \mathrm{Ge}\right\}_{2} . \\
\operatorname{Mg}\left(\eta^{2}-\mathrm{dme}\right)_{2} \\
\text { (colourless) }\end{array}$ & \begin{tabular}{|l} 
tr \\
$\mathrm{P}-1$ \\
4
\end{tabular} & $\begin{array}{l}9.375(1) \\
16.809(5) \\
17.769(3)\end{array}$ & $\begin{array}{l}116.47(1) \\
99.85(1) \\
98.25(2)\end{array}$ & $\begin{array}{l}\mathrm{GeC}_{3} \mathrm{Mg} \\
\mathrm{MgO}_{4} \mathrm{Ge}_{2} \\
\\
\mathrm{GeC}_{3} \mathrm{Mg} \\
\mathrm{MgO}_{4} \mathrm{Ge}_{2}\end{array}$ & $\begin{array}{r}\mathrm{MeC} 1.78(4,4) \\
2.00(3,3) \\
\eta^{2} \mathrm{O} 2.22(1,4) \\
\\
\\
\\
\\
\\
\mathrm{MeC} 1.96(3,4) \\
\eta^{2} \mathrm{O} 2.115(2,1) \\
2.28(2,4)\end{array}$ & 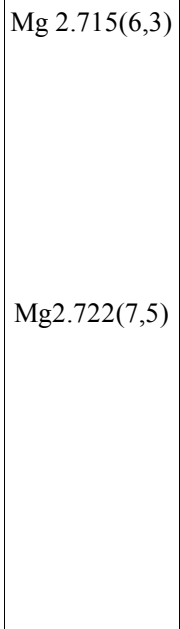 & $\begin{array}{c}\text { C,C } 98(1,4) \\
\\
\text { O,O } 73.0(5,6)^{\mathrm{c}} \\
85.1(5,4.7) \\
154.5(5) \\
\text { O,Ge } 95.8(4,6.6) \\
\text { Ge,Ge } 166.9(4,1.2) \\
99.4(2) \\
\text { C,C } 98(1,3) \\
\text { O,O } 74.2(6,3)^{\mathrm{c}} \\
82.1(6,3.8) \\
151.8(6) \\
\text { O,Ge } 96.5(5,6.1) \\
169.1(5,1) \\
\text { Ge,Ge } 99.2(2)\end{array}$ & [12] \\
\hline $\begin{array}{l}{\left[\mathrm{Me}_{3} \mathrm{GeRu}(\mathrm{CO})_{2} .\right.} \\
\left(\mu-\mathrm{C}_{8} \mathrm{H}_{6}\right)\left(\mathrm{CO}_{2}\right) . \\
\left.\mathrm{RuGeMe}_{3}\right] \\
\text { (pale yellow) }\end{array}$ & $\begin{array}{l}\mathrm{m} \\
\mathrm{P} 2_{1} \\
4\end{array}$ & $\begin{array}{l}9.395(3) \\
22.555(9) \\
10.984(5)\end{array}$ & $96.93(7)$ & $\begin{array}{l}\mathrm{GeC}_{3} \mathrm{Ru} \\
\mathrm{RuC}_{7} \mathrm{Ge} \\
\mathrm{GeC}_{3} \mathrm{Ru} \\
\mathrm{RuC}_{7} \mathrm{Ge}\end{array}$ & $\begin{array}{l}\text { MeC } 1.92(6,9) \\
\text { OC } 1.77(4,3) \\
\text { C } 2.35(4,23) \\
\text { MeC } 1.88(5,16) \\
\text { OC } 1.84(4,6) \\
\text { C } 2.33(4,25)\end{array}$ & $\begin{array}{c}\text { Ru 2.481(5,5) } \\
\text { Ru 3.056(4) } \\
\\
\operatorname{Ru} 2.487(5,5) \\
\operatorname{Ru} 3.060(4)\end{array}$ & $\begin{array}{c}\text { C,C 107(2,3) } \\
\text { C,Ru 112(2,3) } \\
\text { C,C 93.5(2,3) } \\
\text { C,Ge 83.0(2,1.1) } \\
\text { C,Ru 90.9(3,1.4) } \\
\text { Ge,Ru 171.0(2,1.2) } \\
\text { C,C 107(2,7) } \\
\text { C,Ru 112(2,3) } \\
\text { C,C 90.6(6,1.2) } \\
\text { C,Ge 83.7(10,1.0) } \\
\text { C,Ru 90.4(10,1.5) } \\
\text { Ge,Ru 171.3(2,4) }\end{array}$ & [14] \\
\hline $\begin{array}{l}\left(\eta^{5}-\mathrm{cp}\right) \mathrm{Co}(\mathrm{CO})_{2} \mathrm{Co} \\
\left(\eta^{5}-\mathrm{cp}\right)\left(\mathrm{GeCl}_{2}\right)_{2} \mathrm{Fe}(\mathrm{CO})_{4} \\
\text { (black) }\end{array}$ & $\begin{array}{l}\text { or } \\
\mathrm{P} 2{ }_{2} 2_{1} 2_{1} \\
8\end{array}$ & $\begin{array}{l}39.26(2) \\
12.161(8) \\
9.82(1)\end{array}$ & & $\begin{array}{l}\mathrm{GeCl}_{2} \mathrm{CoFe} \\
\mathrm{CoC}_{7} \mathrm{GeCo} \\
\mathrm{FeC}_{4} \mathrm{Ge}_{2}\end{array}$ & $\begin{array}{r}\text { Cl 2.22(2) } \\
\mu \text { OC } 1.87(3) \\
\text { cpC } 2.10(3) \\
\text { OC } 1.81(4)\end{array}$ & $\begin{array}{l}\text { Co } 2.341(9) \\
\text { Fe } 2.438(4) \\
\text { Co } 2.439(5) \\
\quad \text { C } 95(1)\end{array}$ & $\begin{array}{c}\mathrm{Cl}, \mathrm{Cl} \text { 98.7(12) } \\
\mathrm{Co}, \mathrm{Fe} 123.6(8) \\
\mathrm{C}, \mathrm{Ge} 87.6(10) \\
\mathrm{Ge}, \mathrm{Co}{ }^{\prime} 102.0(8) \\
\text { C,C 93(3) } \\
\mathrm{Ge}, \mathrm{Ge} 88.2(2)\end{array}$ & [16] \\
\hline $\begin{array}{l}\left(\mathrm{NEt}_{4}\right)\left[\{\mathrm{CO})_{12}\right. \\
\left.(\mu-\mathrm{CO})_{4} \mathrm{Co}_{5}\right\}\left(\mu_{5}-\mathrm{Ge}\right] \\
(\text { red black })\end{array}$ & $\begin{array}{l}\text { or } \\
\operatorname{Pn} 2_{1} \\
8\end{array}$ & $\begin{array}{l}12.014(1) \\
36.938(4) \\
15.249(2)\end{array}$ & & $\begin{array}{l}\mathrm{GeCo}_{5} \\
\mathrm{CoC}_{4} \mathrm{GeCo}, \\
\mathrm{GeCO}_{5} \\
\mathrm{CoC}_{4} \mathrm{GeCo}^{\prime}\end{array}$ & $\begin{array}{r}\mu O C \quad 1.63-2.04 \\
\text { OC } 1.54-2.03\end{array}$ & $\begin{array}{c}\text { Co } 2.35(1) \\
2.47(1,4) \\
\text { Co } 2.54(1,2) \\
\\
\text { Co } 2.33(1) \\
2.46(1,2) \\
\text { Co } 2.52(1,2)\end{array}$ & $\begin{array}{l}\text { Co,Co 62.5(-,5) } \\
\text { Co,Co 60(-,1) } \\
\text { Ge,Co 59(-,1) } \\
\text { Co,Co 63(-,1) } \\
\text { Co,Co } 60 \\
\text { Ge,Co } 59.5(-, 5)\end{array}$ & {$[17]$} \\
\hline
\end{tabular}

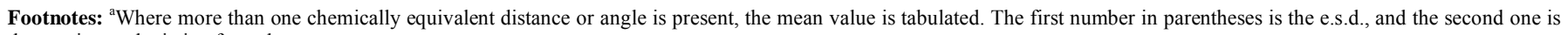
the maximum deviation from the mean.

${ }^{\mathrm{b}}$ The chemical identity of the coordinated atom or ligand is specified in the columns.

${ }^{c}$ Five-membered metallocyclic ring.

${ }^{\mathrm{d}}$ There are three crystallographically independent molecules. 

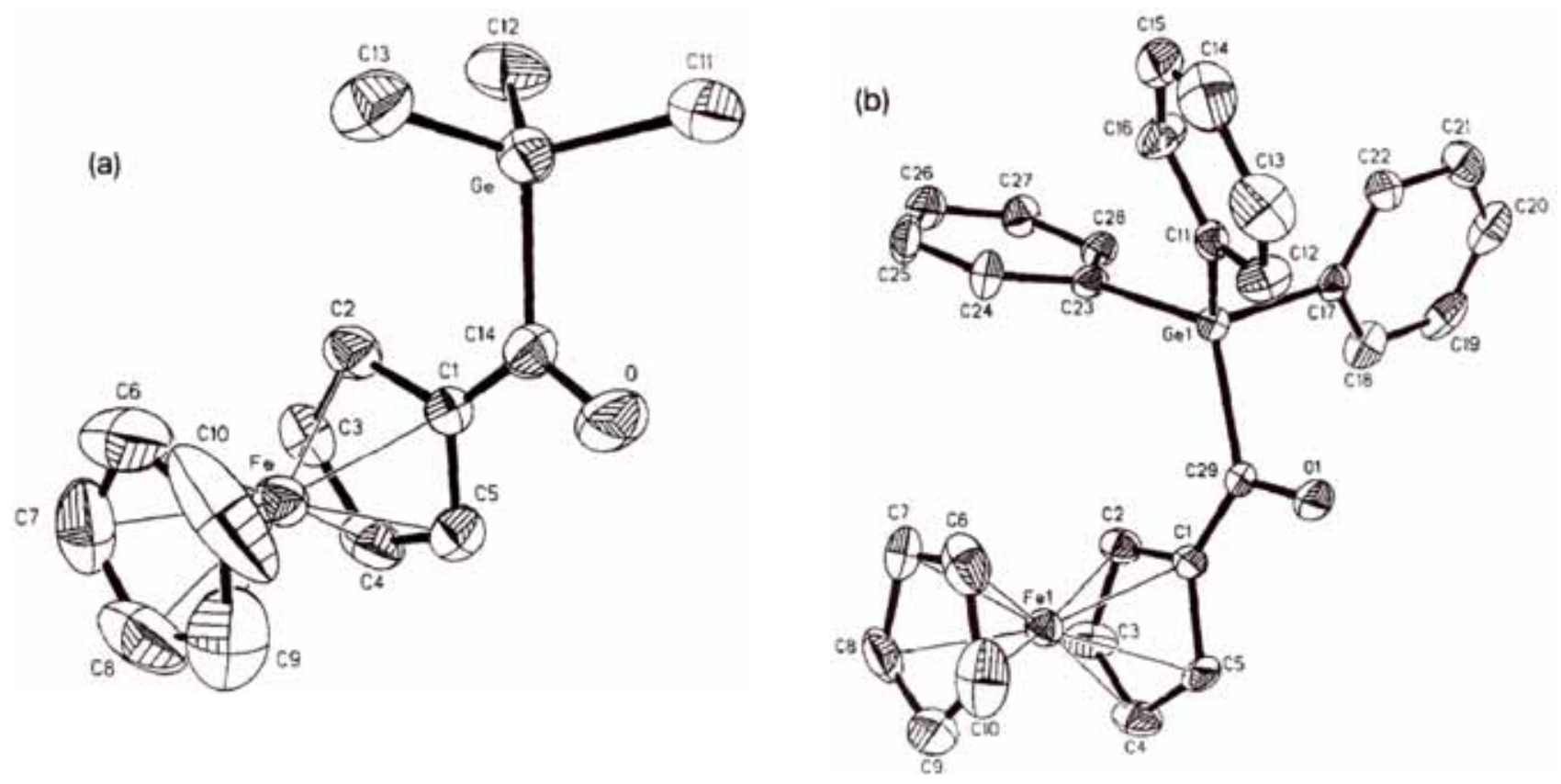

Fig. (1). Structure of two independent molecules of [ $\left.\left(\mathrm{PPh}_{3}\right) \mathrm{Ge}\left(\mu-\mathrm{C}_{5} \mathrm{H}_{4} \mathrm{CO}\right) \mathrm{Fe}(\mathrm{cp})\right]$ [9].

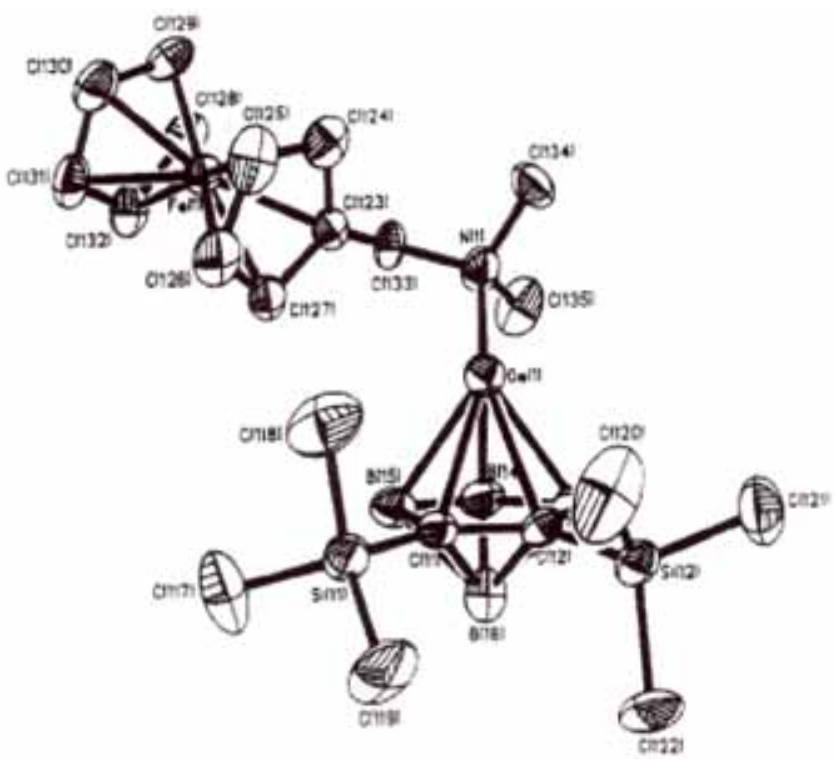

Fig. (2). Structure of $\left[\left\{\left(\mathrm{Me}_{3} \mathrm{Si}_{2}\right)_{2} \mathrm{C}_{2} \mathrm{~B}_{4} \mathrm{H}_{4}\right\} \mathrm{Ge}\left\{\mathrm{N}(\mathrm{Me})_{2} \mathrm{CH}_{2} \mathrm{C}_{5} \mathrm{H}_{4}\right\}\right.$ $\mathrm{Fe}(\mathrm{cp})][10]$.

There are three trimers, a colourless $\mathrm{Ge}_{2} \mathrm{Hg}$ [11], $\mathrm{Ge}_{2} \mathrm{Mg}$ [12] and orange $\mathrm{GeMn}_{2}$ [13], while the $\mathrm{Ge}_{2} \mathrm{Hg}$ and $\mathrm{Ge}_{2} \mathrm{Mg}$ $[11,12]$ contains two, the $\mathrm{GeMn}_{2}$ three crystallographically independent molecules (Table 1). In $\mathrm{Ge}_{2} \mathrm{Hg}$ [11] two equivalent $\mathrm{Ph}_{3} \mathrm{Ge}$ moieties are held together by a direct $\mathrm{Ge}-\mathrm{Hg}$ bond distances with the mean values of $2.514 \AA$ in molecule one and $2.543 \AA$ in another one. The three metal atoms form a linear chain, $\mathrm{Ge}-\mathrm{Hg}-\mathrm{Ge}, 178.65(5)$ and $180.0^{\circ}$, respectively. Structure of the $\mathrm{Ge}_{2} \mathrm{Mg}$ trimer [12] contains a $\mathrm{Ge}-$ $\mathrm{Mg}-\mathrm{Ge}$ chain with different degrees of distortion from the linearity. The mean $\mathrm{Ge}-\mathrm{Mg}$ bond distances are 2.715 and $2.722 \AA$, respectively. Each Ge atom is tetrahedrally coordinated $\left(\mathrm{GeC}_{3} \mathrm{Mg}\right)$ and $\mathrm{Mg}$ is octahedrally $\left(\mathrm{MgO}_{4} \mathrm{Ge}_{2}\right)$.
Structure of $\mathrm{GeMn}_{2}$ trimer [13] contains a $\mathrm{Mn}-\mathrm{Ge}-\mathrm{Mn}$ chain with the mean $\mathrm{Ge}-\mathrm{Mn}$ bond distance of 2.18(2) $\AA$ and $\mathrm{Mn}-\mathrm{Ge}-\mathrm{Mn}$ angle of $179(1)^{\circ}$. Unfortunately, the data are available only for one trimer.

The structure of a pale yellow $\mathrm{Ge}_{2} \mathrm{Ru}_{2}$ tetramer [14] (Fig. 3) shows a pentalene ligand bonded to a nearly linear Ge-Ru$\mathrm{Ru}-\mathrm{Ge}$ spine. The two $\mathrm{C}$ atoms common to both rings are bonded to both $\mathrm{Ru}$ atoms in the form of a trans verge bridge. The remaining two groups of three $\mathrm{C}$ atoms of the pentalene are each bonded to individual $\eta$ - allyl interannular unit to one $\mathrm{Ru}$ atom. The trimethylgermyl groups adopt an eclipsed configuration with respect to the bond axis. The two $\mathrm{CO}$ groups attached to each $\mathrm{Ru}$ atom are likewise eclipsed and mutually orthogonal. There are two crystallographically independent tetramers differing by degree of distortion. The M - $\mathrm{M}$ distances are $\mathrm{Ge}-\mathrm{Ru} 2.481 \AA$, (mean) and $\mathrm{Ru}-\mathrm{Ru}$ $3.0546(4) \AA$ in one tetramer, and $2.487 \AA$ (mean) and 3.060(4) $\AA$, in another one. Each Ge atom has a tetrahedral arrangement $\left(\mathrm{GeC}_{3} \mathrm{Ru}\right)$ and $\mathrm{Ru}$ atom is a semisandwich with two additional $\mathrm{C}(\mathrm{CO})$ atoms and $\mathrm{Ge}\left(\mathrm{RuC}_{7} \mathrm{Ge}\right)$ (Table $\left.\mathbf{1}\right)$.

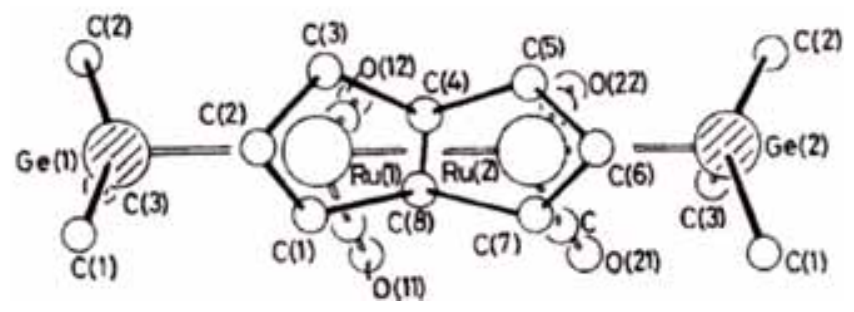

Fig. (3). Structure of $\left[\left\{\mathrm{Me}_{3} \mathrm{GeRu}(\mathrm{CO})_{2}\right\}_{2}\left(\mu-\mathrm{C}_{8} \mathrm{H}_{6}\right)\right][14]$.

The structure of red $\left\{(\mathrm{CO})_{4} \mathrm{Fe}\right\}_{4}\left(\mu_{4}-\mathrm{Ge}\right)$ pentamer [15] contains a $\mathrm{GeFe}_{4}$ skeleton with two $\mathrm{Fe}-\mathrm{Fe}$ single bonds. There are two crystallographically independent clusters with the mean $\mathrm{Ge}-\mathrm{Fe}$ and $\mathrm{Fe}-\mathrm{Fe}$ bond lengths of 2.405(2) and $2.827(3) \AA$ in one; and 2.409(2) and 2.820(3) $\AA$ in the other. 
Noticeably, the sum of all six $\mathrm{M}-\mathrm{M}$ bond lengths in the two independent clusters is almost the same 15.275 and 15.268 $\AA$. Each $\mathrm{Ge}$ atom has a tetrahedral arrangement $\left(\mathrm{GeFe}_{4}\right)$ and $\mathrm{Fe}$ atoms are six-coordinated $\left(\mathrm{FeC}_{4} \mathrm{GeFe}^{\prime}\right)$ (Table 1).

Structure of black $\left\{(\mathrm{cp})(\mathrm{CO}) \mathrm{Co}_{2}\left(\mathrm{GeCl}_{2}\right)_{2} \mathrm{Fe}(\mathrm{CO})_{4}\right.$ pentamer [16] is shown in Fig. (4). The structure contains a planar five membered Co-Ge-Fe-Ge-Co heterometal ring with the following bond distances: Co-Ge, 2.341(9) $\AA$, Ge-Fe,

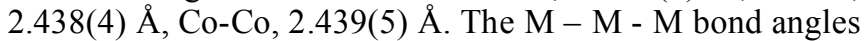
close up in the order: $\mathrm{Co}-\mathrm{Ge}-\mathrm{Fe}, 123.6(8)^{\circ}>\mathrm{Ge}-\mathrm{Co}-$ $\mathrm{Co}^{\prime}, 102(8)^{\circ}>\mathrm{Ge}-\mathrm{Fe}-\mathrm{Ge}, 88.2(2)^{\circ}$. There are two crystallographically independent clusters, but only for one data are available.

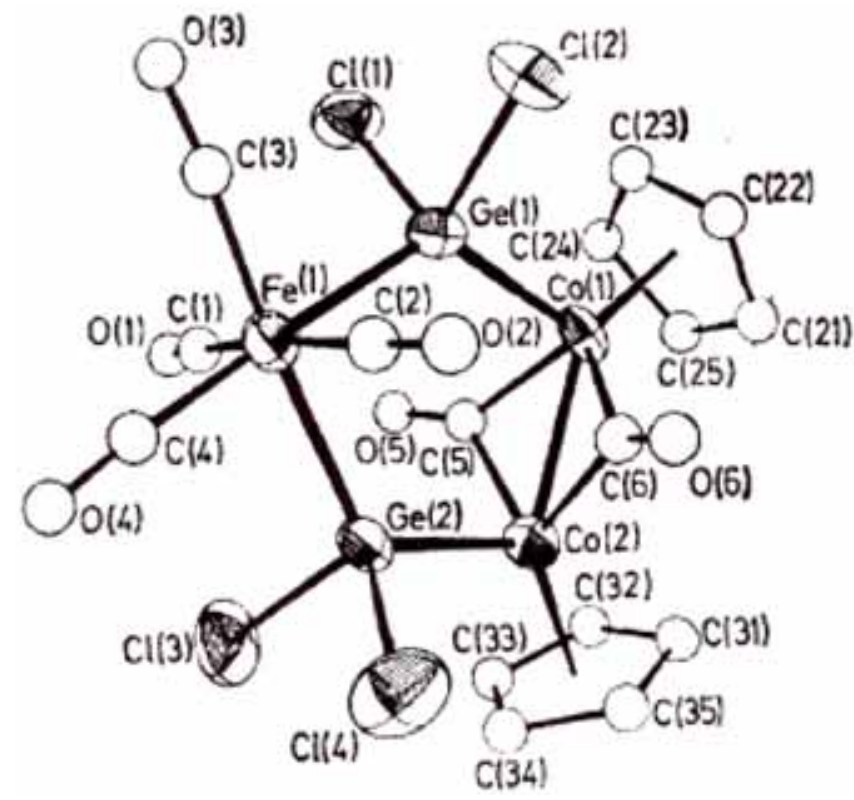

Fig. (4). Structure of $\{(\mathrm{cp})(\mathrm{CO}) \mathrm{Co}\}_{2}\left(\mathrm{GeCl}_{2}\right)_{2} \mathrm{Fe}(\mathrm{CO})_{4}[16]$.

Finally, there is a red black $\mathrm{GeCo}_{5}$ clusters [17], which contains $\mathrm{NEt}_{4}{ }^{+}$cation and $\left[\left\{(\mathrm{CO})_{12}(\mu-\mathrm{CO})_{4} \mathrm{Co}_{5}\right\}\left(\mu_{5}-\mathrm{Ge}\right)\right]^{-}$ anion. Structure of the cluster anion is shown in Fig. (5). The anion has a $\mathrm{GeCo}_{5}$ skeleton consisting of a $\mathrm{GeCo}_{2}$ triangle and $\mathrm{GeCo}_{3}$ tetrahedron sharing a common apex at the $\mathrm{Ge}$ atom, which is thus involved in five Ge-Co bonds. These range in length from 2.35-2.51(1) $\AA$ in one cluster and 2.332.48(1) $\AA$ in another one. The Co - Co bonds range from 2.52-2.56(1) $\AA$ and 2.50-2.54(1) $\AA$, respectively. Both Co atoms of the $\mathrm{GeCo}_{2}$ fragment are bonded to three carbonyl groups, one of them acting as a bridge between them. The Co atoms of the $\mathrm{GeCo}_{3}$ unit each have two terminal carbonyl groups, with an additional $\mathrm{CO}$ ligand along each edge of the $\mathrm{Co}_{3}$ triangle. The $\mathrm{Ge}$ atom has a square pyramidal environment $\left(\mathrm{GeCo}_{5}\right)$ with the mean $\mathrm{Ge}-\mathrm{Co}$ bond distances in plane $2.47 \AA$ in one cluster and $2.46 \AA$ in another one, which are somewhat longer than that of the $\mathrm{Ge}-\mathrm{Co}$ (apical) bond distances of 2.35 and $2.33 \AA$, respectively. These two crystallographically independent clusters are examples of distortion isomerism (Table 1).

Inspection of the data in Table 1 reveals that there are three types of crystal classes: monoclinic (x 6), triclinic (x 5) and orthorhombic (x 3). In the series of distortion isomers, coordination numbers about Ge are: $\mathrm{GeMn}_{2}$ [13], $\mathrm{GeC}_{4}$ [9], $\mathrm{GeCl}_{3} \mathrm{Au}$ [5], $\mathrm{GeC}_{3} \mathrm{M}$ (M = Cu [6], $\mathrm{Mn}$ [7], $\mathrm{Sn}[8], \mathrm{Mg}$ [12] and $\mathrm{Ru}$ [14]), $\mathrm{GeFe}_{4}$ [15], $\mathrm{GeCl}_{2} \mathrm{CoFe}$ [16], $\mathrm{GeB}_{2} \mathrm{C}_{2} \mathrm{~N}$ [10], and $\mathrm{GeCo}_{5}$ [17]. Coordination numbers about $\mathrm{M}$ are $\mathrm{HgGe}_{2}$ [11], $\mathrm{CuP}_{2} \mathrm{Ge}$ [6], $\mathrm{AuP}_{3} \mathrm{Ge}$ [5], $\mathrm{SnC}_{3} \mathrm{Ge}$ [8], $\mathrm{MnC}_{5} \mathrm{Ge}$ [7], $\mathrm{MgO}_{4} \mathrm{Ge}_{2}$ [12], $\mathrm{FeC}_{4} \mathrm{Ge}_{2}$ [16], $\mathrm{FeC}_{4} \mathrm{GeFe}$ [15], $\mathrm{CoC}_{4} \mathrm{GeCo}$ [17], $\mathrm{MnC}_{7} \mathrm{Ge}$ [13], $\mathrm{RuC}_{7} \mathrm{Ge}$ [14], $\mathrm{CoC}_{7} \mathrm{GeCo}$ [16], and $\mathrm{FeC}_{10}$ (sandwich) $[9,10]$.

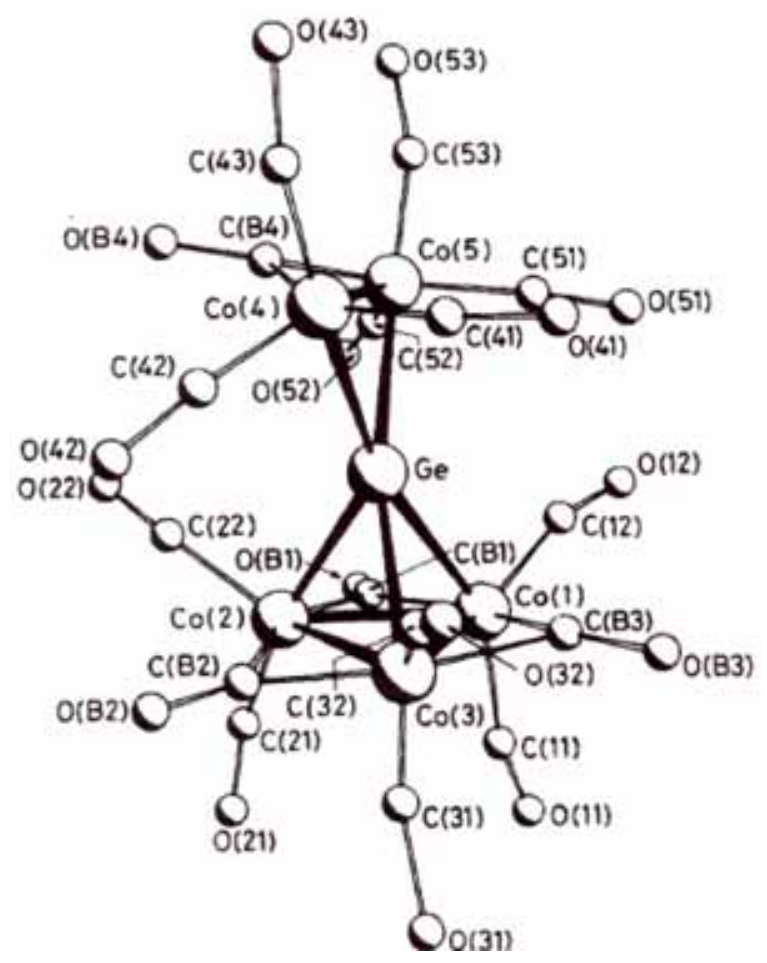

Fig. (5). Structure of $\left[\left\{(\mathrm{CO})_{12}(\mu-\mathrm{CO})_{4} \mathrm{Co}_{5}\right\}\left(\mu_{5}-\mathrm{Ge}\right)\right][17]$.

The shortest $\mathrm{Ge}-\mathrm{M}(\mathrm{M}=$ group $\mathrm{A}$ or group $\mathrm{B})$ bond distance here is for $\mathrm{Ge}-\mathrm{Hg}, 2.514(2) \AA[11]$ and $\mathrm{Ge}-\mathrm{Mn}$ 2.18(2) $\AA[13]$.

\section{CIS - TRANS ISOMERISM}

White $\left(\mathrm{Cl}_{3} \mathrm{Ge}\right)_{2} \mathrm{Ru}(\mathrm{CO})_{4}[18]$ is only example, which exists in two isomeric forms, cis- and trans-, and the former contains two crystallographically independent molecules (Table 2). Both geometric isomers are monoclinic. The three metal atoms form an unsymmetrical triangle with the mean Ge-Ru bond lengths in cis isomer of $2.469 \AA$ (molecule 1) and $2.478 \AA$ (molecule 2), and 2.477(1) $\AA$ in trans- isomer. The $\mathrm{Ge}-\mathrm{Ru}-\mathrm{Ge}$ angles are 90.5(1) and $91.5(2)^{\circ}$ in cis- isomer. Each $\mathrm{Ge}$ atom is a tetrahedrally coordinated $\left(\mathrm{GeCl}_{3} \mathrm{Ru}\right)$ and $\mathrm{Ru}$ atom is an octahedrally coordinated $\left(\mathrm{RuC}_{4} \mathrm{Ge}_{2}\right)(\mathrm{Ta}$ ble 2).

\section{CONCLUSIONS}

Sixteen isomers of heterometallic germanium clusters have been included in this review. There are two types of isomerism - distortion and cis- trans. The former by far prevails (x 15). A yellow $\mathrm{Cl}_{3} \mathrm{GeAu}\left(\mathrm{PPh}_{3}\right)_{3}$ [5] exists in two isomeric forms. An orange $\left\{\left(\mathrm{cp}^{*}\right)(\mathrm{CO})_{2} \mathrm{Mn}\right\}_{2}(\mu-\mathrm{Ge})$ [13] contains within the same crystal three independent molecules. 
Table 2. Crystallographic and Structural Data for Germanium Heterometallic Compounds - Cis-Trans Isomers ${ }^{\mathrm{a}}$

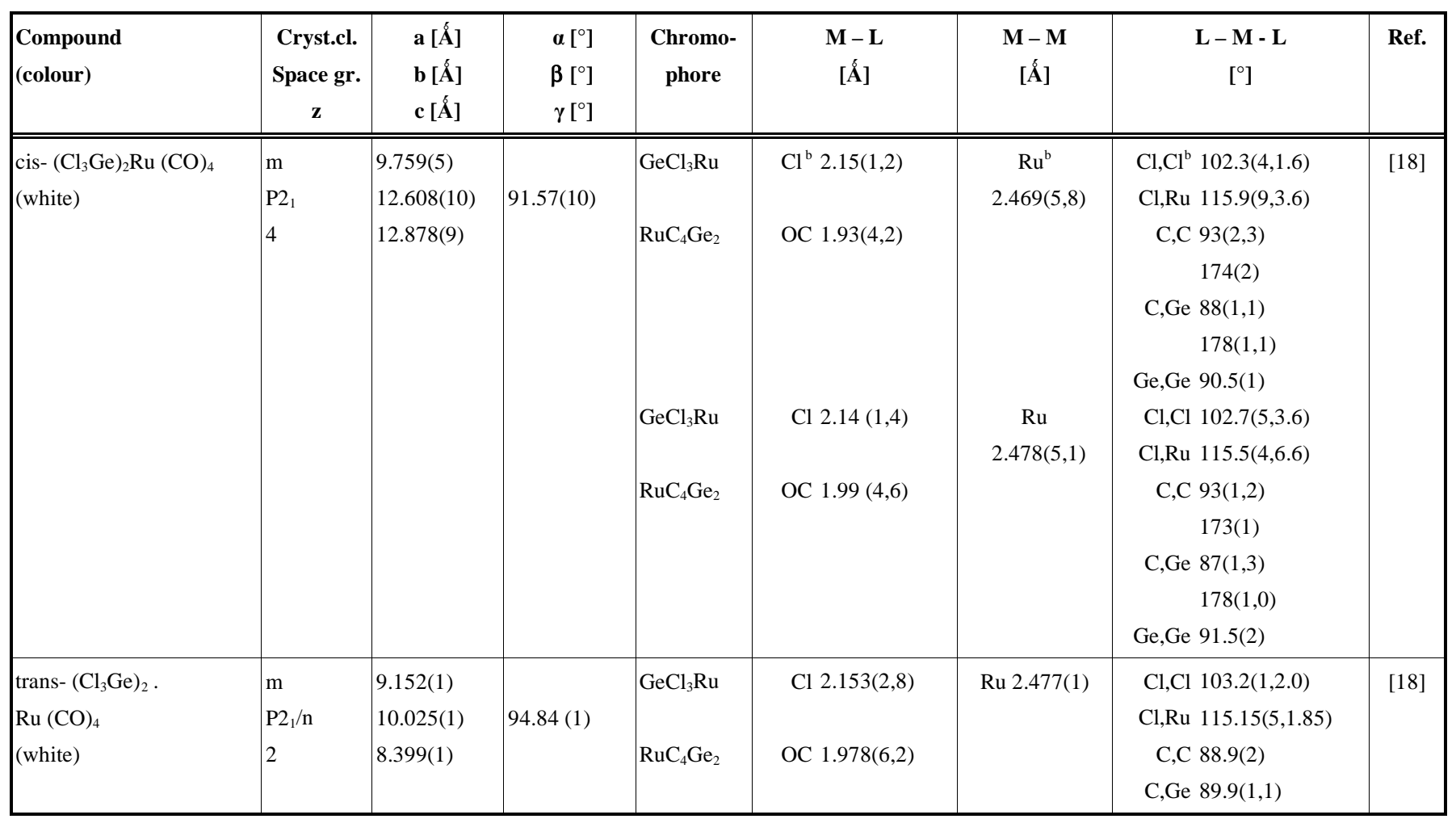

Footnotes: aWhere more than one chemically equivalent distance or angle is present, the mean value is tabulated. The first member in parentheses is the e.s.d., and the second one is the maximum deviation from the mean.

${ }^{\mathrm{b}}$ The chemical identity of the coordinated atom or ligand is specified in these columns.

Remainders contain two such molecules. Also cis$\left\{\mathrm{Cl}_{3} \mathrm{Ge}\right\}_{2} \mathrm{Ru}(\mathrm{CO})_{4}[18]$ contains two such molecules. All are examples of distortion isomerism.
Summary of germanium - metal bond distances found in the series of distortion isomers are given in Table 3. Although germanium is classified as a soft, class B metal atom,

Table 3. Summary of the Ge-M Bond Distances in Heterometallic Germanium Clusters - Distortion Isomers

\begin{tabular}{|l|l|l|l|l|}
\hline \multirow{2}{*}{ Ge-M } & \multicolumn{2}{|c|}{ Isomers [Á] } & Ref. \\
\cline { 2 - 5 } & I. & & $2.536(1)$ & {$[5]$} \\
\hline \hline $\mathrm{Ge}-\mathrm{Au}$ & $2.561(1)$ & & $2.382(3)$ & {$[6]$} \\
\hline $\mathrm{Ge}-\mathrm{Cu}$ & $2.370(2)$ & & $2.54(2)$ & {$[7]$} \\
\hline $\mathrm{Ge}-\mathrm{Mn}$ & $2.53(2)$ & & $2.567(6)$ & {$[8]$} \\
\hline $\mathrm{Ge}-\mathrm{Sn}$ & $2.596(6)$ & & $2.543(2)$ & {$[11]$} \\
\hline $\mathrm{Ge}-\mathrm{Hg}$ & $2.514(2)$ & $2.722(6,5)^{\mathrm{a}}$ & {$[12]$} \\
\hline $\mathrm{Ge}-\mathrm{Mg}$ & $2.715(6,3)^{\mathrm{a}}$ & & {$[13]$} \\
\hline $\mathrm{Ge}-\mathrm{Mn}$ & & & $2.18(2)^{\mathrm{b}}$ & {$[14]$} \\
\hline $\mathrm{Ge}-\mathrm{Ru}$ & $2.481(5,5)^{\mathrm{a}}$ & $2.378(2,0)^{\mathrm{a}}$ & {$[15]$} \\
\hline $\mathrm{Ge}-\mathrm{Fe}$ & $2.394(2,6)^{\mathrm{a}}$ & & $2.419(2,10)^{\mathrm{a}}$ & {$[16)^{\mathrm{a}}$} \\
\hline & $2.425(2,14)^{\mathrm{a}}$ & & {$[16]$} \\
\hline $\mathrm{Ge}-\mathrm{Co}$ & & & & {$[17]$} \\
\hline $\mathrm{Ge}-\mathrm{Fe}$ & & $2.438(4)^{\mathrm{b}}$ & & $2.39(1,7)^{\mathrm{a}}$ \\
\hline $\mathrm{Ge}-\mathrm{Co}$ & $2.41(1,6)^{\mathrm{a}}$ & & $2.478(5,1)^{\mathrm{a}}$ & {$[18]$} \\
\hline $\mathrm{Ge}-\mathrm{Ru}$ & $2.469(5,8)^{\mathrm{a}}$ & & \\
\hline
\end{tabular}

${ }^{\mathrm{a}}$ The mean values are tabulated. The first number in parenthesis is e.s.d., and the second is maximum deviation from the mean.

${ }^{\mathrm{b}}$ Only the mean value was given in original paper. 
it is apparent that it binds to both soft B and hard class A heterometal atom. The shortest $\mathrm{Ge}-\mathrm{M}(\mathrm{M}=$ group $\mathrm{A}$ or group B) bond distances here is for $\mathrm{Ge}-\mathrm{Hg}, 2.514(2)$ [11] and for $\mathrm{Ge}-\mathrm{Mn}, 2.18(2) \AA$ [13].

The mean $\mathrm{Ge}-\mathrm{Ru}$ bond distances of $2.469 \AA$ in cis$\left(\mathrm{Cl}_{3} \mathrm{Ge}\right)_{2} \mathrm{Ru}(\mathrm{CO})$ [18] is about $0.008 \AA$ shorter than that in trans- $\left(\mathrm{Cl}_{3} \mathrm{Ge}_{2} \mathrm{Ru}(\mathrm{CO})_{4}[18](2.477 \AA)\right.$.

This review and its precursors [2, 3] give the first overall survey of the structural data for the isomers of germanium complexes. In the chemistry of germanium coordination compounds [2] two types of isomers were found: distortion (twenty examples) and configuration (two examples). In the chemistry of organogermanium derivatives [3] were also found two types of isomers: a distortion (over forty examples) and ligand isomers (two examples). In general, in the chemistry of germanium complexes by far prevails a distortion isomerism, while cis-trans configuration and ligand isomerism are not so frequent.

This review and its precursors [2, 3, 19-23] give the first overall survey of the structural data for isomer complexes of the group IV metals.

In the chemistry of the group IV metal complexes exists four hundred as isomers, with the seventy four examples in the chemistry of germanium [2,3 and present review], two hundred and fifty six of tin [19-22] and seventy of lead complexes [23]. The isomers exists in the following crystal classes: monoclinic (x 38) > triclinic (x 27) > orthorhombic (x 7) > tetragonal and cubic, each (x 1) in the chemistry of germanium; monoclinic $(x$ 125) $>$ triclinic $(x$ 75) $>$ orthorhombic $(x$ 38) $>$ tetragonal $(x$ 12) $>$ trigonal $(x$ 3) $>$ hexagonal (x 2) and cubic (x 1) in the chemistry of tin; and monoclinic $(x$ 31) $>\operatorname{triclinic}(x$ 23) $>$ orthorhombic $(x \quad 8)>$ tetragonal (x 4) $>$ trigonal (x 2) $>$ hexagonal and cubic, each (x 1) in the chemistry of lead. One can see that the monoclinic $(48 \%)$ and triclinic $(31.25 \%)$ by far prevail in the chemistry of isomers of the respective the group IV metals.

Structural data of all four hundred isomers showed that stereoisomers dominate in the chemistry of the group IV metals. Included are distortion (x 68) > ligand, cis-trans and configuration, each ( $\mathrm{x} 2$ ) isomerism, in the chemistry of germanium; distortion $(x$ 238) $>$ ligand (x 12) > cis-trans (x $5)>$ polymerisation ( $x \quad 1)$ isomerism in the chemistry of tin; and distortion $(x$ 44) $>$ ligand $(x$ 12) $>$ coordination $(x$ 9) $>$ polymerisation (x 5) isomerism, in the chemistry of lead. In general, the number of isomers in the group IV metal complexes increases in the order: distortion (x 350, 87.5\%) > ligand $(\mathrm{x} 26,6.5 \%)>$ coordination $(\mathrm{x} 9,2.35 \%)>$ cis-trans $(7,1.75 \%)>$ polymerisation $(\mathrm{x} 6,1.5 \%)>$ configuration $(\mathrm{x}$ $2,0.5 \%$ ). Only two types of isomerism (configuration and polymerisation) belong to the structural class, remainders are stereoisomers. Distortion isomerisation is far more common with two crystallographically independent molecules within the same crystal.

Interestingly, that in the chemistry of transition elements like for example copper $\mathrm{Cu}(\mathrm{II})$ [4], $\mathrm{Cu}(\mathrm{I})$ [24] and platinum [25]) also distortion isomers with a monoclinic class dominate.

It is hoped that such a review will help to focus attention on areas of transition as well as non transition chemistry that could be enhanced by further study and assist in allowing comparative behaviour of the respective metal atoms in the situation which can arise from the widespread use of metals.

\section{ACKNOWLEDGEMENTS}

The authors wish to thank those who gave permission for reproduction of original figures, and the Ministry of Education of the Slovak Republic, APVV-20-005504 and VEGA $1 / 0353 / 08$ for financial support.

\section{ABBREVIATIONS}

$\begin{array}{ll}\mathrm{C}_{6} \mathrm{~F}_{5} & =\text { pentafluorophenyl } \\ \mathrm{cp} & =\text { cyclopentadienyl } \\ \mathrm{cp}^{*} & =\text { pentamethylcyclopentadienyl } \\ \mathrm{dme} & =1,2 \text {-dimethoxyethane } \\ \mathrm{Et} & =\text { ethyl } \\ \mathrm{m} & =\text { monoclinic } \\ \mathrm{Me} & =\text { methyl } \\ \mathrm{or} & =\text { orthorhombic } \\ \mathrm{Ph} & =\text { phenyl } \\ \mathrm{PPh}_{3} & =\text { triphenylphosphine } \\ \mathrm{tr} & =\text { triclinic }\end{array}$

\section{REFERENCES}

[1] Holloway, C.E.; Melník, M. Main Group Met. Chem., 2002, 25, 331.

[2] Melnik, M.; Garaj, J. Open Inorg. Chem. J., 2008, 2, 56

[3] Melnik, M.; Garaj, J. Open Inorg. Chem. J., 2008, 2, 94.

[4] Melnik, M. Coord. Chem. Rev., 1982, 47, 239.

[5] Bauer, A.; Schier, A.; Schmidbau, H. J. Chem. Soc. Dalton Trans., 1995, 2919.

[6] Orlov, N.A.; Bochtarev, L.N.; Nikitinsky, A.V.; Krupotova, V.Y.; Zakcharov, L.N.; Fukin, G.K.; Khoisev, S.Y. J. Organomet. Chem., 1998, 560, 21.

[7] Kilbourn, B.T.; Blundell, T.L.; Powell, M. J. Chem. Soc. Chem. Commun., 1965, 444.

[8] Parkanyi, L.; Kalman, A.; Panne, K.H.l.; Sharma, H. J. Organomet. Chem., 1994, 484, 153.

[9] Sharma, H.K.; Cervantes-Lee, F.; Pannel, K.H. J. Organomet. Chem., 1991, 409, 321.

[10] Hamane, N.S.; Kai-Juan, L.; Hongming, Z.; Maguire, J.A.; Lei, Y.; Bareto, R.D. Organometallics, 1992, 11, 2458.

[11] Titova, S.N.; Bychkov, V.T.; Domachov, G.A.; Razuvaev, G.A.; Zakharov, L.N.; Alexandrov, G.G.; Struchkov, Y.T. Inorg. Chim. Acta, 1981, 50, 71 .

[12] Rosch, L.; Krieger, C.; Chiang, A.P. Z. Naturforsch., 1984, 396, 855.

[13] Korp, J.D.; Bernal, I.; Hörlein, R.; Seraano, R.; Hermann, W.A. Chem. Ber., 1985, 118, 340.

[14] Howard, J.A.K.; Woodword, P. J. Chem. Soc. Dalton Trans., 1978 5,412 .

[15] Melzer, D.; Weiss, E. J. Organomet. Chem., 1983, 255, 335.

[16] Edler, M.; Hutcheon, W.L. J. Chem. Soc. Dalton Trans., 1972, 2, 175.

[17] Croft, R.A.; Duffy, D.M.; Nicholson, B.K. J. Chem. Soc. Dalton Trans., 1982, 6, 1023.

[18] Ball, R.; Bennet, M.J. Inorg. Chem., 1972, 11, 1806.

[19] Melnik, M.; Garaj, J.; Valent, A.; Kohutová, M. Trends Inorg. Chem., 2009, in press.

[20] Melnik, M.; Garaj, J.; Valent, A.; Kohutova, M. ICFAI Univ. J. Chem., 2008, $1,36$.

[21] Melnik, M.; Garaj, J.; Valent, A.; Kohutova, M. Main Group Met. Chem., 2009, in press.

[22] Melnik, M. Main Group Met. Chem., 2009, in press. 
[23] Melnik, M.; Garaj, J.; Holloway, C.E. Main Group Met. Chem., 2008, 30, 309.

[24] Melnik, M.; Garaj, J. Trends Inorg. Chem., 2006, 9, 45.

Received: October 21, 2008

(C) Melník and Garaj; Licensee Bentham Open.

This is an open access article licensed under the terms of the Creative Commons Attribution Non-Commercial License (http://creativecommons.org/licenses/by-nc/3.0/) which permits unrestricted, non-commercial use, distribution and reproduction in any medium, provided the work is properly cited. 